\title{
MODEL OPTIMISASI UNTUK MASALAH MINIMISASI BIAYA PERJALANAN WISATA TUR-TUNGGAL DI ZONA KEPULAUAN
}

\author{
M. T. Afifudin ${ }^{1 *}$, D. P. Sahar ${ }^{2}$ \\ ${ }^{1}$ Jurusan Teknik Industri, Fakultas Teknik, Universitas Pattimura, Ambon, 97234 \\ *Email: thezar.afifudin@fatek.unpatti.ac.id \\ 2Jurusan Teknik Industri, Fakultas Teknik, Universitas Pattimura, Ambon, 97234 \\ Email: dian.sahar@fatek.unpatti.ac.id
}

\begin{abstract}
Abstrak. Tujuan penelitian ini adalah untuk mengembangkan model optimisasi penyelesaian masalah minimisasi biaya perjalanan wisata tur-tunggal di zona kepulauan. Model dikembangkan dengan menggunakan pendekatan integer non-linier programming dengan mempertimbangkan seleksi titik keberangkatan dan kedatangan suatu pulau, seleksi titik akomodasi, seleksi jadwal keberangkatan moda transportasi, dan seleksi rute perjalanan baik di dalam pulau maupun antar pulau. Komponen biaya yang dilihat meliputi biaya perjalanan antar-pulau, biaya perjalanan darat, biaya di titik-titik selektif, dan biaya menunggu keberangkatan. Percobaan numerik dilakukan terhadap kasus perencanaan rute wisata di Maluku, Indonesia. Skenario hari keberangkatan dibangun untuk mengetahui rute dan jadwal yang tepat di setiap hari keberangkatan dengan total biaya minimum. Selain itu, perbandingan juga dilakukan terhadap hasil yang didapat pada model minimisasi waktu yang telah diperkenalkan sebelumnya. Hasil penelitian menunjukkan bahwa model dapat beradaptasi melalui variasi solusi terhadap perubahan parameter dan tujuan yang diberikan.
\end{abstract}

Kata kunci: pengrutean, penjadwalan,kepulauan, intermoda

\begin{abstract}
This study aims to develop an optimization model for solving the insular cost minimization single-tour travel problems. The model was developed using an integer nonlinear programming approach by considering the selection of departure and arrival points of an island, selecting accommodation points, selecting transportation mode departure schedules, and selecting travel routes both within islands and between islands. The cost components considered include inter-island travel costs, land travel costs, costs at selective points, and costs waiting for departure. A numerical experiment was conducted on the case of planning a tourist route in Maluku, Indonesia. The departure day scenario is built to find out the exact route and schedule on each day of departure with a minimum total cost. In addition, comparisons were also made to the results obtained in the time minimization model that was introduced earlier. The results showed that the model can adapt through variations of solutions to changes in the given parameters and objectives.
\end{abstract}

Keywords: routing, scheduling, insular, intermoda

\section{PENDAHULUAN}

Teknologi informasi memudahkan suatu organisasi atau industri dapat menyajikan secara langsung apa yang diinginkan kostumernya. Tidak terkecuali pada industri pariwisata, pengembangan aplikasi dilakukan untuk memudahkan turis merencanakan secara pribadi perjalanan wisata yang diinginkan secaramobile.
Pembahasan mengenai aplikasi tidak terlepas dari masalah dan model penyelesaian yang digunakan di dalamnya. Terkait dengan perjalanan wisata, masalah yang populer dibahas oleh komunitas riset operasional saat ini adalah tourist trip design problem (TTDP).

TTDP atau dikenal juga dengan tour route plan problem (TRPP) didefinisikan sebagai masalah perencanaan rute tur dalam mengunjungi sejumlah 
titik wisata yang diinginkan (point of interest POI) [1]. Masalah ini memiliki korespondensi dengan orienteering problem (OP) dan vehicle routing problem (VRP) [2,3]. Ekstensi dan varian TTDP dibagi menjadi dua kelompok [4]. Pertama, single-tour TTDP yang dikembangkan dari OP (varian TSP), difokuskan untuk masalah perjalanan yang bersifat individual atau personal. Kedua, multi-tour TTDP yang dikembangkan dari team OP (TOP), varian VRP, untuk perjalanan kelompok atau tim.

Dalam artikel ini, pembahasan difokuskan pada varian single-tour TTDP dengan mempertimbangkan zona klaster kepulauan. Masalah ini bersinggungan dengan varian-varian OP dan TSP dengan karakteristikclustered generalized. Secara parsial, clustered digunakan untuk masalah perjalanan antar-klaster dimana semua titik (pada klaster) harus dikunjungi $[5,6]$, sedangkan generalized digunakan untuk perjalanan antar-klaster dimana representasi kunjungan ke klaster hanya dapat diwakili minimal oleh satu titik [7,8]. Clustered generalized memungkinkan setiap klaster dapat terbentuk dari klaster-klaster yang lebih kecil.

Aplikasiclustered generalizedpada masalah perencanaan rutepertama kali diperkenalkan dalam masalah logistik, seperti penempatan dan pengambilan barang oleh robotic automated storage and retrieval system (ASRS) dan pengiriman barang dengan drone [9]. Namun, model tersebut sulit diaplikasikan untuk masalah perencanaan rute di zona kepulauan. Ini disebabkan karena setiap klaster kecil hanya dapat dikunjungi sekali.

Pada kunjungan di zona kepulauan, klaster pulau terbentuk dari minimal dua jenis klaster kecil, yaitu (1) klaster titik koneksi antar pulau $(C P)$ yang terdiri dari pelabuhan, bandara, dan sebagainya, dan (2) klaster titik tujuan. Kunjungan terhadap klaster $C P$ minimal dilakukan sebanyak dua kali, sebagai titik kedatangan dan keberangkatan [10-13]. Oleh karena itu, di setiap pulau, akan diseleksi minimal satu $C P$.

Pengembangannya terkait dengan perjalanan tur, seleksi titik tidak hanya dilakukan pada titik koneksi, melainkan juga titik akomodasi. Masalah ini mirip dengan varian-varian OP dan VRP dengan hotel selection [14][15], dimana maksimum skor capaian ke sejumlah POI bergantung pada hotel-hotel yang diseleksi, diawali dari hotel dan kembali ke hotel.

Perencanaan rute tur di zona kepulauan dengan mempertimbangkan seleksi titik akomodasi telah diperkenalkan sebelumnya oleh Afifudin \& Sahar [16]. Dalam artikel tersebut, model optimisasi dibangun dengan tujuan untuk meminimisasi waktu. Berbeda dengan masalah dalam artikel ini, model optimisasi dibangun untuk tujuan minimisasi biaya. Hal ini didasari pada kenyataan bahwa waktu tidak selalu menjadi prioritas bagi turis, melainkan juga diperlukan trade-off dengan biaya.

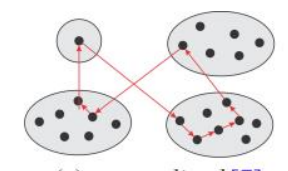

(a) generalized [7]

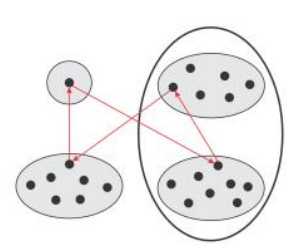

(c) clustered generalized [9]

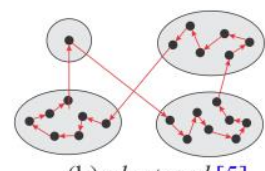

(b) clustered [5]

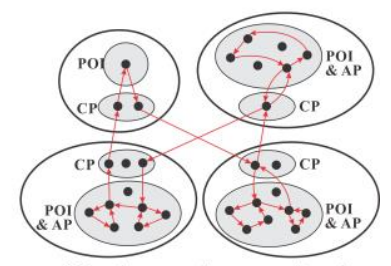
(d) clustered generalized
di zona kepulauan [16]
Gambar 1. Jenis klasterisasi masalah perutean

Riset-riset terkait TTDP sebelumnya telah memperkenalkan beragam pendekatan penyelesaian, baik eksak, heuristik, maupun metaheuristik [4]. Dalam penelitian ini, model dibangun dengan menggunakan pendekatan eksak pemrograman integer non-linier. Untuk mencapai tujuan model, maka estimasi total biaya direncanakan meliputi biaya perjalanan antarpulau, biaya perjalanan darat, biaya di titik koneksi, titik akomodasi, dan titik wisata, dan biaya menunggu keberangkatan (delay) moda transportasi.

Seleksi titik akomodasi (accommodation point - $A P$ ) berpengaruh terhadap biaya yang dikeluarkan. Dalam kasus ini, seleksi titik akomodasi didasarkan pada kemampuan waktu jangkau ke POI-POI. AP akan mengkover suatu $P O I$ jika waktu perjalanan antar keduanya kurang dari kemampuan waktu jangkau $A P$. Semakin banyak $P O I$ yang dikover, menyebabkan bertambahnya waktu yang dibutuhkan di AP. Meningkatnya waktu akomodasi, menyebabkan peningkatan pada biaya yang dikeluarkan.

Pengaruh waktu terhadap biaya juga terjadi pada proses menunggu keberangkatan moda transportasi. Semakin lama waktu menunggu, menyebabkan semakin meningkatnya biaya menunggu. Oleh karena itu seleksi titik dan rute perlu dioptimalkan tidak hanya untuk meminimisasi biaya perjalanan dan akomodasi, melainkan juga biaya menunggu keberangkatan di titik koneksi $C P$. 


\section{METODE DAN BAHAN}

\subsection{Metode}

Model yang dikembangkan dalam penelitian ini menggunakan pendekatan dan teknik yang sama dilakukan oleh Afifudin \& Sahar [16]. Pendekatan pengembangan model menggunakan integer nonlinear programming (INLP). Untuk mengestimasi biaya total, maka komponen biaya dibagi menjadi enam, yaitu (1) biaya perjalanan antar titik koneksiAC, (2) biaya perjalanan antar $A P$ dan/atau $P O I$, (3) biaya perjalanan dari $C P$ ke $A P,(4)$ biaya perjalanan dari $A P$ ke $C P$, (5) biaya selama proses di $C P$, dan (6) biaya sewa $A P$ dan/atau kunjungan ke POI. Gambar 2 mengilustrasikan jenis-jenis perjalanan. Untuk penentuan biaya-biaya tersebut, maka seleksi diperlukan terhadap titik konektivitas di suatu pulau (titik keberangkatan dan kedatangan), seleksi titik akomodasi, seleksi jadwal keberangkatan moda, dan seleksi rute perjalanan (dalam dan antar pulau).

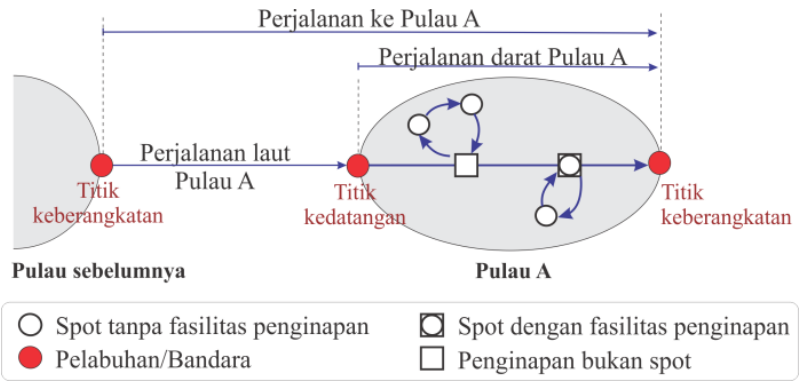

Gambar 2. Ilustrasi perjalanan ke suatu pulau

Pengujian model dilakukan melalui percobaan numerikal untuk menganalisis adapatabilitas model dalam memberikan variasi solusi terhadap 14 skenario yang direncanakan. Skenario didasarkan pada variasi hari keberangkatan (7 hari) dan kemampuan waktu kover titik akomodasi dalam menjangkau POI-POI. Kemampuan waktu kover $(\max C)$ dibagi menjadi dua, yaitu normal dan ekstrim. MaxC ekstrim dirancang agar model hanya menyeleksi satu titik akomodasi $(A P)$ yang dapat mengkover semua $P O I$ yang akan dikunjungi di setiap pulau. Sedangkan MaxC normal dirancang agar model dapat memilih lebih dari satu AP.

Selain itu, perbandingan hasil dilakukan terhadap model lainnya (minimisasi waktu) untuk melihat sejauh mana perilaku dan variasi solusi yang diberikan terhadap perubahan tujuan.

\subsection{Bahan}

Set data [17] yang digunakan dalam pengujian model dikembangkan dari salah satu kasus yang dihadapi di kepulauan Maluku. Set data tersebut memuat parameter pengujian model yang memuat dataterkait 13 titik (POI/AP), 5 pulau, 10 titik koneksi $(C P)$, dan 54 jadwal keberangkatan selama waktu perencanaan.

\section{HASIL DAN PEMBAHASAN}

\subsection{Notasi dan Teknik Formulasi}

Graf sistem masalah dalam artikel ini terdiri dari beberapa set (himpunan) dan directed link yang dideskripsikan sebagai berikut. $Q^{1}$ merupakan set pulau sebanyak $N^{1}$, dimana setiap pulau diindeks dengan $A, B$, atau $C . Q^{2}$ merupakan set titik koneksi antar pulau (seperti pelabuhan dan bandara) sebanyak $N^{2}$, dimana setiap titik koneksi diindeks dengan $D, E$, atau $F . Q^{3}$ merupakan set titik (meliputi titik akomodasi dan titik wisata) sebanyak $N^{3}$, dimana setiap titik diindeks dengan $G, \quad H$, atau $I . Q^{4}$ merupakan set waktu keberangkatan sebanyak $N^{4}$, dimana setiap waktu keberangkatan diindeks dengan $J$. Setiap set saling terhubung melalui directed link yang direpresentasikan oleh parameter-parameter dan variabel-variabel yang digunakan.

Parameter-parameter dan variabel-variabel yang digunakan meliputi yang digunakan oleh Afifudin \& Sahar [16] dan penambahan beberapa parameter dan variabel sebagai berikut:

Parameter model

$C_{D e l}=$ Biaya menunggu

Variabel-variabel keputusan

$C A_{D, E}=$ Biaya perjalanan antar titik koneksi pulau dari $D$ ke $E$

$C B_{G, H}=$ Biaya perjalanan antar AP/POI dari $G$ ke $H$

$C C_{D, G}=$ Biaya perjalanan dari titik koneksi $D$ ke AP $G$

$C D_{G, D}=$ Biaya perjalanan dari AP $G$ ke titik koneksi $D$

$C E_{D}=$ Biaya selama proses load-unload muatan di titik koneksi $D$

$C F_{G}=$ Biaya sewa $\mathrm{AP}$ dan/atau kunjungan ke POI $G$

Variabel-variabel tambahan

$X D_{G}=1$, jika $X A_{G}=0$ dan $X B_{G}=1$; dan 0 , jika tidak

$T G_{G}=$ Akumulasi waktu di POI $G$

$T H_{A, G}=$ Akumulasi waktu di AP $G$ di pulau $A$ berdasarkan lamanya waktu kunjungan ke semua POI yang dikovernya

$C T_{A}=$ Jumlah biaya dibutuhkan untuk mengunjungi pulau $A$ mulai dari keberangkatan dari pulau sebelumnya sampai tiba di titik keberangkatan pulau $A$ 


\subsection{FormulaMatematis}

a. Tujuan

$$
\begin{gathered}
\text { Minimize } C+C_{D e l}\left[\operatorname{Max}\left(T T S_{A}\right)+T T_{1}-\operatorname{Min}\left(T T S_{A}\right)-T\right] \\
\sum_{D} \sum_{E} W A_{D, E} \cdot C A_{D, E}+\sum_{G} \sum_{H} W B_{G, H} \cdot C B_{G, H}+ \\
\sum_{D} \sum_{G}^{D} W C_{D, G} \cdot C C_{D, G}+\sum_{G} \sum_{D} W D_{G, D} \cdot C D_{G, D}+ \\
\sum_{G}^{G} \sum_{H} \sum_{I} W F_{G, H, I} \cdot C B_{H, I}+\sum_{A} \sum_{D} Y A_{A, D} \cdot C E_{D}+ \\
\sum_{A}^{A} \sum_{D}^{D} Y B_{A, D} \cdot C E_{D}+\sum_{A} \sum_{G} Z B_{A, G} \cdot X D_{G} \cdot T G_{G} \cdot C F_{G}+ \\
\sum_{A}^{A} \sum_{G}^{G}\left(1-Y C_{A, G}\right) \cdot Z B_{A, G} \cdot X A_{G} \cdot X B_{G} \cdot T G_{G} \cdot C F_{G}+ \\
\sum_{A} \sum_{G} Y C_{A, G} \cdot Z B_{A, G} \cdot X A_{G} \cdot T H_{G} \cdot C F_{G} \\
C \geq\left(\sum_{G} X B_{G} \cdot C F_{G}\right)+\left(N_{1} \cdot 2 \cdot \operatorname{Min}\left(C E_{D}\right)\right)
\end{gathered}
$$

Ekuasi (1) merupakan fungsi tujuan minimisasi biaya total. $C$ merupakan jumlah biaya perjalanan, biaya penginapan, dan biaya kunjungan di spot (lihat Ekuasi 2), sedangkan $C_{\mathrm{Del}}\left[\operatorname{Max}\left(T T S_{\mathrm{A}}\right)+T T_{1^{-}}\right.$ $\left.\operatorname{Min}\left(T T S_{\mathrm{A}}\right)-T\right]$ merupakan jumlah biaya selama menunggu keberangkatan. Ekuasi (3) mengatur nilai batas bawah (lower bound) untuk $C$.

\section{b. Kendala-kendala}

Untuk mencapai tujuan minimisasi biaya, maka kendala-kendala yang dihadapi meliputi:

1). Kendala-kendala yang digunakan oleh

Afifudin \& Sahar(Ekuasi 2 - 68) [16]:

dimana $\Psi$ meliputi:

- penentuan waktu keberangkatan total TT

- penentuan lower bound (batas bawah) dari total waktu keberangkatan dan waktu keberangkatan dari pulau terakhir dikunjungi

- penentuan rute antar pelabuhan

- penentuan titik penginapan di suatu pulau

- penentuan rute antar titik penginapan di suatu pulau

- penentuan rute antar titik kedatangan dengan titik penginapan di suatu pulau

- penentuan rute antar titik penginapan dengan titik keberangkatan di suatu pulau

- penentuan konektivitas rute antar titik penginapan dengan titik kedatangan dan titik keberangkatan di suatu pulau

- penentuan pengkoveran titik penginapan terhadap spot-spot wisata di suatu pulau

- penentuan rute antar spot wisata dan dengan titik penginapan di suatu pulau

- penentuan waktu keberangkatan dari suatu pulau

- penentuan akumulasi waktu di suatu pulau
- penentuan waktu mulai perjalanan dari setiap urutan pulau.

2). Penentuan akumulasi biaya di suatu pulau

$$
\begin{aligned}
& \sum_{B \neq A} \sum_{D} \sum_{E \neq D} W A_{D, E} Z A_{B, D} \cdot Z A_{A, E} \cdot C A_{D, E}+ \\
& \sum_{G} \sum_{H} W B_{G, H} \cdot Z B_{A, G} \cdot Z B_{A, H} \cdot C B_{G, H}+ \\
& \sum_{D}^{G} \sum_{G}^{H} W C_{D, G} \cdot Z A_{A, D} \cdot Z B_{A, G} \cdot C C_{D, G}+
\end{aligned}
$$

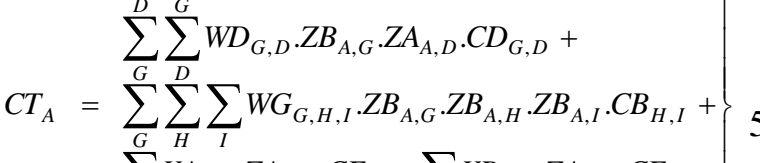

$$
\begin{aligned}
& \sum_{D}^{G} Y A_{A, D} \cdot Z A_{A, D} \cdot C E_{D}+\sum_{D} Y B_{A, D} \cdot Z A_{A, D} \cdot C E_{D}+ \\
& \sum_{G}^{D} Z B_{A, G} \cdot X D_{G} \cdot T G_{G} \cdot C F_{G}+ \\
& \sum_{G}^{G} Y C_{A, G} \cdot Z B_{A, G} \cdot X A_{G} \cdot T H_{A, G} \cdot C F_{G}+ \\
& \sum_{G}^{G}\left(1-Y C_{A, G}\right) \cdot Z B_{A, G} \cdot X A_{G} \cdot X B_{G} \cdot T G_{G} \cdot C F_{G} \\
& ; \forall A \in Q^{1} \\
& X D_{G}=\left\{\begin{array}{ll}
1, & X A_{G}=0, X B_{G}=1 \\
0, & \text { lainnya }
\end{array} ; \forall G \in Q^{3} \quad 6\right. \\
& T G_{G}=I N T \quad ; \forall G \in Q^{3} \\
& \left(\frac{T F_{G}}{24}\right) X B_{G} \leq T G_{G} \leq\left(\frac{T F_{G}}{24}\right) X B_{G}+1 ; \forall G \in Q^{3} \quad 8 \\
& T H_{G}=I N T \quad ; \forall G \in Q^{3} \\
& \left.\begin{array}{r}
T H_{G} \geq\left(\frac{\sum_{H} W E_{G, H} \cdot Z B_{A, G} \cdot Z B_{A, H} \cdot T F_{H}}{24}\right) \\
T H_{G} \leq\left(\frac{\sum_{H} W E_{G, H} \cdot Z B_{A, G} \cdot Z B_{A, H} \cdot T F_{H}}{24}\right)+1
\end{array}\right\} ; \forall G \in Q^{3}
\end{aligned}
$$

Ekuasi (5) merupakan akumulasi biaya di suatu pulau $C T$. Ekuasi (6) menjelaskan $X D$ merupakan variabel integer binari yang digunakan untuk menjelaskan bahwa suatu spot wisata tidak memiliki fasilitas penginapan. Ekuasi (7) menjelaskan $T G$ sebagai variabel integer general untuk mengakumulasi waktu dalam satuan hari di setiap spot wisata. Ekuasi (8) menyatakan $T H$ sebagai akumulasi jumlah waktu yang diperlukan di setiap penginapan dalam mengkover seluruh spot wisata. Ekuasi (9-10) menyatakan batasan nilai $T H$.

\subsection{Percobaan Numerikal dan Pembahasan}

Percobaan numerikal dilakukan terhadap model berdasarkan pada skenario dan set data yang diberikan. Untuk melihat lebih jelas performa yang diberikan model, maka perbandingan hasil dilakukan dengan model minimisasi waktu yang diperkenalkan sebelumnya [16]. Tabel 1 menyajikan rangkuman hasil yang diberikan kedua 
model dilihat pada tipe rute, jam keberangkatan dari pulau original, jumlah waktu dan biaya perjalanan antar pulau, jumlah waktu dan biaya perjalanan darat, jumlah waktu dan biaya proses di titik-titik selektif, jumlah waktu dan biaya menunggu keberangkatan (delay), lama kunjungan wisata (makespan), dan biaya total.

a. Hasil percobaan numerikal pada model masalah minimisasi biaya

Dari Tabel 1 dapat dijelaskan, bahwa pada MaxC normal (=0.9 jam), terdapat dua tipe solusi optimal yang diberikan model untuk mencapai tujuan yang diinginkan untuk hari-hari keberangkatan. Solusi tipe I berlaku untuk keberangkatan yang dimulai pada hari Senin, Kamis, atau Sabtu, sedangkan solusi tipe II untuk keberangkatan yang dimulai pada hari Selasa, Rabu, Jumat, atau Minggu. Solusi tipe I merekomendasikan rute 1 sebagai rute optimal (lihat Gambar 3), dimana biaya total yang dikeluarkan sebesar $15.64\left(x R p .10^{5}\right)$ dengan waktu wisata selama 6.3 hari (makespan $=151.83 \mathrm{jam})$.
Berbeda dengan solusi tipe II merekomendasikan rute 2 sebagai rute optimal dengan biaya total sebesar 15.76 (xRp.105) dan waktu wisata selama 7.3 hari.

Perbedaan biaya total dari kedua solusi sebagian besar disebabkan karena proses menunggu (delay) keberangkatan moda transportasi antar-pulau dan perjalanan antar-pulau. Meningkatnya biaya total pada solusi tipe II disebabkan karena proses delay, dimana selisihnya dengan solusi tipe I sebesar 0.23 $\left(x R p .10^{5}\right)$ atau meningkat $177 \%$. Namun, jika dilihat pada biaya perjalanan antar-pulau, biaya yang diberikan solusi tipe II lebih efisien $4 \%$ dibandingkan dengan solusi tipe I.

Untuk skenario MaxC dinaikkan secara ekstrim (=1.5 jam), keberangkatan yang dimulai pada semua hari mengerucut pada satu solusi optimal. Untuk mencapai biaya total minimum, maka perjalanan dilakukan dengan menggunakan rute 3 . Dengan rute tersebut, maka biaya total yang dicapai sebesar 15.39 (xRp.10 ${ }^{5}$ ) dengan waktu wisata kurang lebih selama 6.5 hari (makespan $=$ 156.14 jam).

Tabel 1. Perbandingan waktu dan biaya antara dua model (minimisasi biaya dan minimisasi waktu)

\begin{tabular}{|c|c|c|c|c|c|c|c|c|c|c|c|c|c|}
\hline \multicolumn{2}{|c|}{ Skenario } & \multirow{2}{*}{ 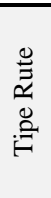 } & \multirow{2}{*}{$\begin{array}{c}\text { Jam } \\
\text { berangkat } \\
\text { dari pulau } \\
\text { original }\end{array}$} & \multirow{2}{*}{$\begin{array}{c}\Sigma \text { Waktu } \\
\text { perjalanan } \\
\text { antar- } \\
\text { pulau } \\
\text { (jam) }\end{array}$} & \multirow{2}{*}{$\begin{array}{c}\Sigma \text { Waktu } \\
\text { perjalanan } \\
\text { darat } \\
\text { (jam) }\end{array}$} & \multirow{2}{*}{$\begin{array}{c}\Sigma \text { Waktu } \\
\text { proses } \\
\text { di titik- } \\
\text { titik } \\
\text { selektif } \\
\text { (jam) }\end{array}$} & \multirow{2}{*}{$\begin{array}{c}\Sigma \\
\text { Waktu } \\
\text { delay } \\
\text { (jam) }\end{array}$} & \multirow{2}{*}{$\begin{array}{l}\text { Make- } \\
\text { span } \\
\text { (jam) }\end{array}$} & \multirow{2}{*}{$\begin{array}{c}\Sigma \text { Biaya } \\
\text { perjalanan } \\
\text { antar- } \\
\text { pulau } \\
\left(\mathrm{Rp} .10^{5}\right)\end{array}$} & \multirow{2}{*}{$\begin{array}{c}\Sigma \text { Biaya } \\
\text { perjalanan } \\
\text { darat } \\
\left(\mathrm{Rp} .10^{5}\right)\end{array}$} & \multirow{2}{*}{$\begin{array}{c}\Sigma \text { Biaya } \\
\text { proses di } \\
\text { titik-titik } \\
\text { selektif } \\
\left(\mathrm{Rp} .10^{5}\right)\end{array}$} & \multirow{2}{*}{$\begin{array}{c}\Sigma \text { Biaya } \\
\text { delay } \\
\left(\mathrm{Rp} .10^{5}\right)\end{array}$} & \multirow{2}{*}{$\begin{array}{c}\text { Biaya } \\
\text { total } \\
\left(\mathrm{Rp} .10^{5}\right)\end{array}$} \\
\hline $\begin{array}{l}\operatorname{Max} C \\
(\mathrm{jam})\end{array}$ & $\begin{array}{c}\text { Hari } \\
\text { berangkat }\end{array}$ & & & & & & & & & & & & \\
\hline 1 & 2 & 3 & 4 & 5 & 6 & 7 & 8 & 9 & 10 & 11 & 12 & 13 & 14 \\
\hline \multicolumn{14}{|c|}{ Minimisasi Biaya } \\
\hline \multirow[t]{2}{*}{$\begin{array}{l}0.9 \\
\text { (rendah/ } \\
\text { normal) }\end{array}$} & $\begin{array}{l}\text { Senin, } \\
\text { Kamis, atau } \\
\text { Sabtu }\end{array}$ & 1 & 6 & 15.03 & 19 & 105.25 & 12.55 & 151.83 & 3.32 & 7.62 & 4.57 & 0.13 & 15.64 \\
\hline & $\begin{array}{l}\text { Selasa, } \\
\text { Rabu, } \\
\text { Jumat, atau } \\
\text { Minggu }\end{array}$ & 2 & 6 & 14.32 & 19.07 & 105.25 & 35.85 & 174.49 & 3.19 & 7.64 & 4.57 & 0.36 & 15.76 \\
\hline $\begin{array}{l}1.5 \\
\text { (ekstrim } \\
\text { tinggi) }\end{array}$ & Semua hari & 3 & 6 & 13.75 & 19.09 & 105.25 & 18.05 & 156.14 & 3.22 & 7.27 & 4.72 & 0.18 & 15.39 \\
\hline \multicolumn{14}{|c|}{ Minimisasi Waktu } \\
\hline 0.9 & Senin & 4 & 12 & 12.56 & 15.8 & 105 & 15.61 & 148.97 & 3.89 & 10.41 & 4.37 & 0.16 & 18.83 \\
\hline \multirow[t]{2}{*}{$\begin{array}{l}\text { (rendah/ } \\
\text { normal) }\end{array}$} & $\begin{array}{l}\text { Selasa, } \\
\text { Kamis, } \\
\text { Sabtu, atau } \\
\text { Minggu }\end{array}$ & 5 & 6 & 13.58 & 15.75 & 105 & 5.63 & 139.96 & 3.66 & 9.71 & 4.37 & 0.06 & 17.8 \\
\hline & $\begin{array}{l}\text { Rabu atau } \\
\text { Jumat }\end{array}$ & 6 & 12 & 12.3 & 15.87 & 105 & 12.76 & 145.93 & 3.85 & 10.43 & 4.37 & 0.13 & 18.78 \\
\hline \multirow{3}{*}{$\begin{array}{l}1.5 \\
\text { (ekstrim } \\
\text { tinggi) }\end{array}$} & Senin & 7 & 12 & 12.56 & 14.68 & 104.5 & 17.23 & 148.97 & 3.89 & 11.4 & 5.92 & 0.17 & 21.38 \\
\hline & $\begin{array}{l}\text { Selasa, } \\
\text { Kamis, } \\
\text { Sabtu, atau } \\
\text { Minggu }\end{array}$ & 8 & 6 & 13.58 & 14.63 & 104.5 & 7.25 & 139.96 & 3.66 & 10.7 & 5.92 & 0.07 & 20.35 \\
\hline & $\begin{array}{l}\text { Rabu atau } \\
\text { Jumat }\end{array}$ & 9 & 12 & 12.3 & 14.79 & 104.5 & 14.34 & 145.93 & 3.85 & 11.6 & 5.92 & 0.14 & 21.51 \\
\hline
\end{tabular}


Rute 1

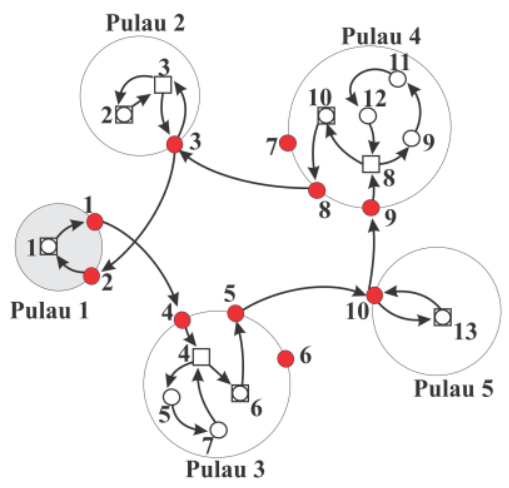

Rute 2

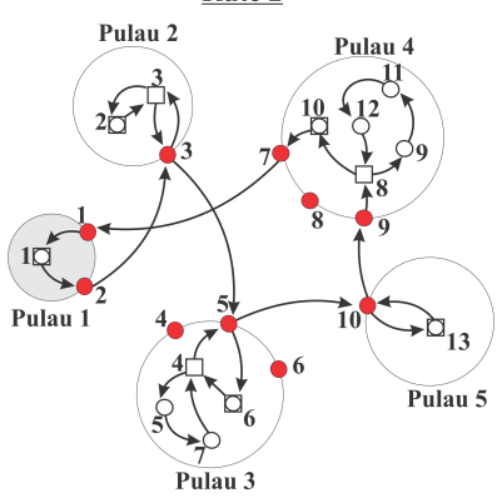

Rute 3

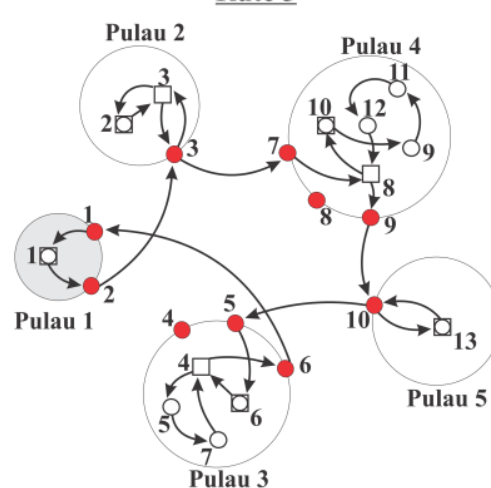

Keterangan:

- titik (meliputi: POI dengan fasilitas akomodasi $=Q$, POI tanpa fasilitas akomodasi $=\bigcirc$, dan titik akomodasi bukan POI $=\square$ ) - titik koneksi antar pulau $(\mathrm{CP})=$

Gambar 3. Tipe rute optimal untuk masalah minimisasi biaya (MMB)

Baik pada MaxC normal ataupun dinaikkan secara ekstrim, kedua kondisi tersebut tidak memperlihatkan adanya variasi pada jumlah biaya proses di titik-titik selektif, untuk setiap hari keberangkatan. Namun jika diperhatikan secara ditel ketiga rute tersebut, terlihat bahwa fenomena ini disebabkan karena adanya kesamaan jumlah titik-titik yang diseleksi oleh setiap solusi.

Dari hasil dan pembahasan di atas, terlihat bahwa model memiliki adaptabilitas terhadap skenario yang diberikan, baik pada perubahan hari keberangkatan maupun kemampuan waktu kover penginapan $(\operatorname{MaxC})$.

b. Perbandingan hasil dengan model masalah minimisasi waktu

Dari Tabel 1 dapat dijelaskan bahwa perbedaan mendasar dari kedua model terlihat pada capaian nilai tujuan dan banyaknya variasi solusi yang ditawarkan. Model minimisasi biaya (MMB) berupaya untuk meminimumkan biaya total, sedangkan model minimisasi waktu (MMW) berupaya untuk meminimumkan waktu total atau lama kunjungan wisata (makespan). Solusi yang ditawarkan MMB tidak terlalu bervariasi dibandingkan dengan MMW. MMB hanya merekomendasikan dua tipe untuk $\operatorname{MaxC}$ rendah (=0.9 jam) dan satu tipe solusi untuk MaxC tinggi (=1.5 jam), sedangkan MMW merekomendasikan tiga tipe solusi, baik untuk MaxC rendah maupun ekstrim tinggi.

Selain perbedaan mendasar di atas, terdapat perbedaan unik yang diberikan oleh kedua model. Perbedaan tersebut dapat dilihat pada perjalanan antar-pulau ketika perubahan MaxC dilakukan. Biaya dan waktu perjalanan antar-pulau untuk setiap hari pada MMW tidak mengalami perubahan ketika MaxC dinaikkan (ke 1.5 jam).
Misalnya, keberangkatan pada hari Senin untuk $\operatorname{MaxC}$ rendah (=0.9 jam) dan untuk MaxC tinggi $(=1.5 \mathrm{jam})$ masing-masing menggunakan rute yang berbeda, yaitu rute 4 dan 7 (lihat Gambar 4).

Namun, keduanya memiliki jumlah waktu antar pulau yang sama (=12.56 jam). Pada kedua rute terlihat bahwa perubahan hanya terjadi pada perjalanan darat. Berbeda dengan keberangkatan hari Senin pada MMB, perubahan MaxC menjadi 1.5 jam memberikan perubahan rute perjalanan (dari rute $1 \mathrm{ke} 3$ ) yang melibatkan tidak hanya pada perjalanan darat, melainkan pula perjalanan antarpulau. Hal ini disebabkan karena pada MMW, rute antar-pulau dipertahankan sehingga tidak terjadi perubahan pada makespan.

Meskipun solusi yang diberikan kedua model bervariasi, namun terdapat persamaan unik yang diberikan oleh keduanya. Persamaan dapat dilihat pada proses di titik-titik selektif. Baik pada skenario MaxC rendah maupun tinggi, keduanya merekomendasikan waktu dan biaya proses (di titik-titik selektif) yang sama. Misalnya untuk MaxC rendah (=0.9 jam), dua tipe solusi yang direkomendasikan MMB memiliki jumlahwaktu proses yang sama sebesar 105.25 jam dengan biaya sebesar $4.57 \quad\left(x R p .10^{5}\right)$, sedangkan MMW merekomendasikan tiga tipe solusi dengan waktu proses yang sama sebesar 105 jam dengan biaya sebesar 4.37 (xRp.10 $10^{5}$ ). Namun, jika dilihat pada rute masing-masing kelompok, keduanya merekomendasikan jumlah titik selektif yang sama, yaitu 23 titik (pada MMW, satu titik koneksi berfungsi ganda sebagai titik kedatangan dan keberangkatan). Hal yang sama juga dapat dilihat ketika MaxC dinaikkan (=1.5 jam). 

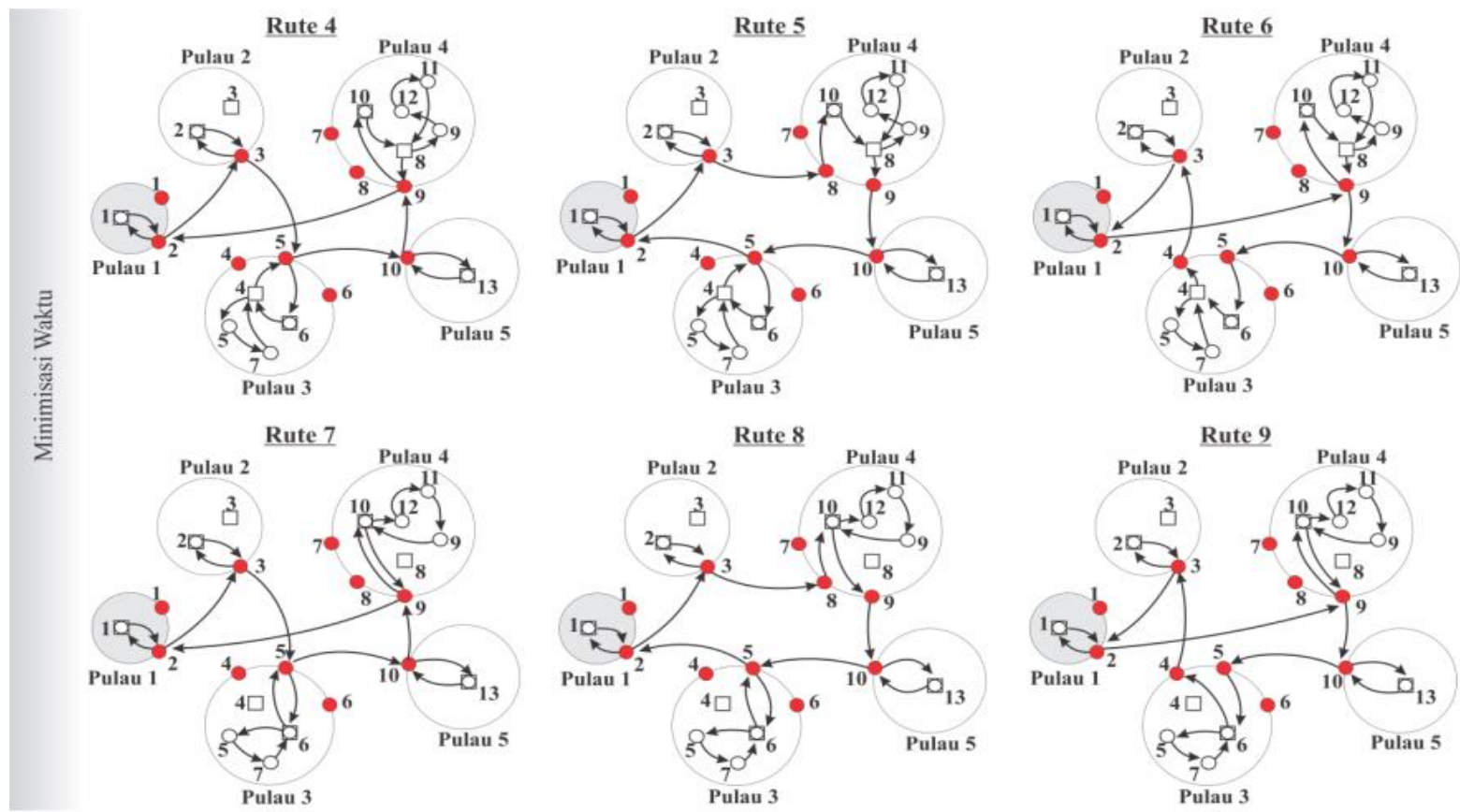

Keterangan:

- titik (meliputi: POI dengan fasilitas akomodasi $=\mathrm{Q}$, POI tanpa fasilitas akomodasi $=\bigcirc$, dan titik akomodasi bukan POI $=\square$ )

- titik koneksi antar pulau $(\mathrm{CP})=$

Gambar 4. Tipe rute optimal untuk masalah minimisasi waktu (MMW)

Dari hasil dan pembahasan di atas, terlihat bahwa model yang dikembangkan (MMB) memiliki konsistensi terhadap tujuan yang dicapai. Untuk mencapai tujuan yang diinginkan, model menunjukkan adaptabilitasnya dengan merekomendasikan variasi solusi yang berbeda dengan model pembandingnya (minimisasi waktu). Selain itu, pada komputer dengan spesifikasi yang sama, rata-rata waktu running MMB sebesar 5.57 menit, sedangkan MMW sebesar 8.23 menit.

\section{KESIMPULAN}

Model optimisasi untuk masalah minimisasi biaya wisata tur-tunggal di zona kepulauan diformulasi dalam bentuk integer non-linear programming dengan mempetimbangkan seleksi titik keberangkatan dan kedatangan suatu pulau, seleksi titik akomodasi, seleksi jadwal keberangkatan moda transportasi, dan seleksi rute perjalanan baik di dalam pulau maupun antar pulau. Komponen biaya yang dilihat meliputi biaya perjalanan antar-pulau, biaya perjalanan darat, biaya di titik-titik selektif, dan biaya menunggu keberangkatan (delay).

Berdasarkan percobaan numerikal yang dilakukan terhadap model, menunjukkan bahwa model mampu menunjukkan adaptabilitasnya terhadap perubahan parameter (hari dan waktu kover) yang diberikan. Model mampu memberikan variasi solusi yang berbeda dan waktu running yang singkat dibandingkan dengan model pembandingnya (minimisasi waktu).

Model ini dapat digunakan bagi wisatawan secara individual atau manajemen (agen) travel/tour dalam menentukan rute wisata di zona kepulauan dengan mempertimbangkan biaya perjalanan. Model ini hanya dapat digunakan untuk masalah yang memiliki batasan sistem sesuai yang diberikan. Untuk penelitian ke depan, karakteristik masalah akan difokuskan pada pengkoveran tunggal (single cover) suatu pulau dengan sifat passing dan penggunaannya pada masalah tim atau kelompok.

\section{UCAPAN TERIMA KASIH}

Penulis berterima kasih kepada Fakultas Teknik Universitas Pattimura untuk mendanai penelitian ini. Artikel ini merupakan salah satu keluaran dari Penelitian Dasar Unggulan Perguruan Tinggi Tahun 2020berdasarkan SK Rektor No. 2010/UN13/SK/2020.

\section{DAFTAR PUSTAKA}

[1] Vansteenwegen, P. and Van Oudheusden, D. (2007) The mobile tourist guide: An OR opportunity. OR Insight. 20 (3), 21-27.

[2] Vansteenwegen, P., Souffriau, W., and Oudheusden, D. Van (2011) The orienteering problem: A survey. European Journal of Operational Research. 209 (1), $1-10$.

[3] Gunawan, A., Ng, K.M., Kendall, G., and 
Lai, J. (2018) An iterated local search algorithm for the team orienteering problem with variable profits. Engineering Optimization. 50 (7), 1148-1163.

[4] Gavalas, D., Konstantopoulos, C., Mastakas, K., and Pantziou, G. (2014) A survey on algorithmic approaches for solving tourist trip design problems. Journal of Heuristics. 20 (3), 291-328.

[5] Laporte, G. and Palekar, U. (2002) Some applications of the clustered travelling salesman problem. Journal of the Operational Research Society. 53 (9), 972976.

[6] Angelelli, E., Archetti, C., and Vindigni, M. (2014) The clustered orienteering problem. European Journal of Operational Research.

[7] Laporte, G., Asef-Vaziri, A., and Sriskandarajah, C. (1996) Some applications of the generalized travelling salesman problem. Journal of the Operational Research Society. 47 (12), 1461-1467.

[8] Geem, Z.W., Tseng, C.L., and Park, Y. (2005) Harmony search for generalized orienteering problem: Best touring in China. Lecture Notes in Computer Science. 3612 (PART III), 741-750.

[9] Baniasadi, P., Foumani, M., Smith-Miles, K., and Ejov, V. (2020) A transformation technique for the clustered generalized traveling salesman problem with applications to logistics. European Journal of Operational Research. 285 (2), 444-457.

[10] Miranda, P.A., Blazquez, C.A., Vergara, R., and Weitzler, S. (2015) A novel methodology for designing a household waste collection system for insular zones. Transportation Research Part E. 77 227247.

[11] González, D.S.A., Olivares-benitez, E., and Miranda, P.A. (2017) Insular biobjective routing with environmental considerations for a solid waste collection system in Southern Chile. Advances in Operations Research. 2017 (2), Article number 4093689.

[12] Miranda, P.A., Blazquez, C.A., Obreque, C., Maturana-ross, J., and Gutierrez-jarpa, G. (2018) The bi-objective insular traveling salesman problem with maritime and ground transportation costs. European Journal of Operational Research.

[13] Afifudin, M.T. and Sahar, D.P. (2020) An integer programming approach for single truck routing-and-scheduling problems to islands with time-varying ferry schedules. Journal of Industrial Engineering \& Management (JIEM). 5 (2), 53-61.

[14] Divsalar, A., Vansteenwegen, P., and Cattrysse, D. (2013) A variable neighborhood search method for the orienteering problem with hotel selection. International Journal of Production Economics. 145 (1), 150-160.

[15] Vansteenwegen, P., Souffriau, W., and Sörensen, K. (2012) The travelling salesperson problem with hotel selection. Journal of the Operational Research Society. 63 (2), 207-217.

[16] Afifudin, M.T. and Sahar, D.P. (2021) Model optimisasi untuk masalah minimisasi waktu perjalanan wisata turtunggal di daerah kepulauan. ARIKA. 15 (1), 15-28.

[17] Afifudin, M.T. (2021) insularTTDP.Mendeley Data, V2, doi: 10.17632/39yhpfp7ct.2 